Tunnard, c. , and

Reed,H.H.

Veblen, Thorstein

Whitman, Walt

$\frac{\text { American Skyline }}{(3 / 6)}$
$\frac{\text { The Theory of the Leisure Class }}{\text { Leaves of Grass }}$
(4/-)

Po.cket Books Inc. (note: this. selection probably represents only a few of the tities available)

Davis, Elmer

Flexner,J.T.

Lilienthal,D.E.

Melville,H.

Morris,R.B. (ed.)

Poe, Edgar A.

But We Were Born Free $\quad \begin{aligned} & (3 / 6) \\ & \text { A History of Araerican Painting }\end{aligned} \quad(2 / 6)$
Big Business: a New Era $(3 / 6)$
Moby Dick (abridged, 3/6)
Basic Ideas of Alexander Hamilton
Great Tales and Poems (3/6)

On American books as a whole, a new nonthly publication, Books from the U.S.A., is distributed by R.R.Bowker ( 62 West West $4 \overline{5 t h}$ Street, New York 36). It is "designed expressly for overseas booksellers, their customers, and libraries -- describing the new books published in the United States. The featured book reviews written especially for the foreign reader are largely adapted from the reviews of the Library Journal. All areas of interest ... are covered." It is sent free "to booksellers and libraries actively interested in U.S. books (one subscription to each)" and at a cost of "落I.50 per year to others abroad, e.g. to an indiviclual who cannot arrange to get it through his bookseller." We have not yet seen a copy, but it sounds as though it might prove valuable to many of our neubers. If possible we will distribute free specimen copies to members.

$* * * * * *$

\title{
OTHER BOOK NEWS
}

A new book that is almost definable as a BAAS publication is British Essays in Arerican History (Edward Arnold, pp. ix, 348, 30/-). Its editors, H.C.Allen and C.P.Hill, are both BAAS members. They have also contributed to the 17 essays in the book. All but two of the other contributors, indeed, are nerbers; and of these two, Professor D.W.Brogan is a nember of the BAAS advisory council. Here is the complete contents list:

J.R.Pole $\ldots \ldots \ldots$...... H. Hale Bellot ...... W.IR.Brock $\ldots \ldots$..... Esliond Wright $\ldots \ldots$. R.H.Pear ............ Frank Thistiethwaite John A. Hawgood ..... H.C.Allen

Maldwyn A.Jones ..... George Shepperson .. Marcus Cunliffe .... C.P.Hill ............ Alan Conway $\ldots \ldots \ldots$. Henry Pelling ........ J.Potter ............ $\operatorname{Max}$ Beloff ........." D.W.Brogan There are brief reading lists, two endpaper riaps and an index.
"The Naking of the Constitution"

"Divided Sovereignty"

"The Ideas and Influence of Alexander Hamilton" "Thorias Jefferson and the Jeffersonian Idea" "Anerican Political Parties"

"Commercial America"

"Manifest Destiny"

"F.J.Turner and the Frontier in Arerican

History"

"Sectionalisw and the Civil War"

"Reconstruction and the Colour Probleri"

"The Awerican Military Tradition"

"American Razicalisi: Jackson, Bryan c.nd Wilisa"

"America, Half Brother of the wrid"

"The Rise of Aiserican Labour"

"Inaustrial Anerica"

"Alerican Foreign Policy and World Power: 1871-1956"

Ainerican Liberalisi Today" 
Professor Samuel Eliot Moris on, of Harvard University, comrents that: "It is an unusual experience for Americens to hear about their own history frod scileone who is not hiuself an American. This book of essays is an expression of the trend of the tires. Thirty years ago it would have been ilipossible to find three historians in England who would have had anything to say about Awerican history; but here, united under one cover, are 17 interesting esseys on different aspects of United States history, frow Colonial tizes to the present ... Every one of them is worth reading $b_{j}$ anyone interested in American history."

We hope that other recctions will be as kind. It would also be nice to think that before long there might be enough scholars in this country to produce a collection of British Essays in Anerican Literature.

George G.Harrap ( 182 High Holborn, Iondon W.C.I) are the British distributors of the excellent Amherst series, Problelus in American Civilization (published in the U.S. by D.C.Heath,Boston). Three new titles in the series, each available fron Harrap at $9 /-$, are The Compromise of 1850; Evolution and Religion; and Wilson at Versailles. There have also been revised editions (1956) of two older titles: The Turner Thesis, and The Declaration of Independence and the Constitution. Ailong other quite recent titles in the series are Immigration - An Anerican Dilemina, Loyalty in a Denocratic State, and Benjanin Franklin and the American Character.

Another noteworthy enterprise is the new Chicago History of American Civilization, under the general editorship of Professor Daniel J. Boorstin. Published by the University of Chicaro Press ( $\$ 3.00$ and 3.50 per volume in hard covers, 1.75 in paper covers), it will consist of some ten "chronnlogical" studies and a siuilar number of "topical" volumes. The first two volumes in the series were Tracy Ellis, Awericen Catholicism, and Edwund S.Morgan, The Birth of the Republic, 1763-1789. Forthccring volures include Herbert Agar, The Price of Pover (Americt since 1945); Nathan Glazer, Judaism in America; and Dexter Perkins, The New Age of Franklin Roosevelt. Two BAAS nembers will be representet. Maldwyn A.Jones is preparing a "topical" voluze on Ariericen iumigration, while Marcus Cunliffe is writing a "chronologicel" acoount of the period 1789-1837.

Our colleagues in Italy have produced two admirable collections of essays ( 1955 and 1956) under the title of Studi Americani. This annual review (price 1200 lire), devoted to the arts and letters of the United States, is published in Rowe by Edizioni di Storin e Letteratura, Via Lancellotti 18, under the direction of Professor Agostino Lonbardo. The 1956 volume, of three hurared pages, contains articles in Italian on Edward Taylor, Erily Dickinson, Havthome, W.D.Howells, Henry James (four articles on the lister!), Cabeli's Jurgen, the Southern short stories of Eudora Welty and Flannery 'Connor, Fobert Lowel1, Lionel Trilling, Saul Bellow, and on Arierican symbolism and the Alerican tradition in literature. Professor Lombardo and his lively ascciates are also bringing out a number of longer studies in a Biblioteca di Studi Arericani. The first of these, alre: dy published, is a work on Thoreau by B iancariaria Tedeschini Lalli.

In Geriany, 1956 saw the appearance of the firstsubstantial volume of another new publication, the Jahrbuch für Aierikastudien (ed. by Dr. Walther Fischer; Heidelberg, Carl Winter Universitatsverlag). It contains nine articles on various aspects of fmerican 
Studies, with - - as might be expected -- particular reference to German-American relationships. We congratulate Dr.Fischer and his colleagues, and look forward to an exchange of views and publications. Future issues of the BAAS Bulletin will. no doubt" contain a fuller account of the Jahrbuch.

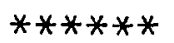

\section{OTHER NEWS}

Dre. Myron I. Koenig, whom many of us had the pleasure of knowing when he was cultural attache at the American Enbassy in L ndon, is now back at his post as professor of history at George Washington University. He retains, however, a keen interest in our doings, which he has sumarized in the April, 1957, issue of American Studies (the newsletter of the American Studies Association).

In his place, we are pleased to welcome Dr. Carl B de, of the University of Maryland. Those who attended the Nottingham conference were able to meet Dr. Bode. We hope to see a lot of him during his tour of duty; for apert from being professor of English at Maryland, and a well-known scholar in the fiela of Americen literature (the editor of Collected Poems of Henry David Thoreau and co-editor of American Heritage, a two-volune anthology), he was the founder and first president of the Arericen Studies Association. His enthusiasms therefore lie very close to ours; and, speaking from a selfish point of view, his is a most havpy cippointment for the BAAS. Dr. Bode's most recent book is The Americen Lyceum: Inwn Meeting of the Mind (New York, Oxford U.P., 1956), a fascinating history of this important lecture-movement, written with a nice edge of humour.

$* * * * * *$

\section{BOOKS RECEIVED}

We acknowledge with thenks the receipt of the following:

-- James Woodress (comp.), Dissertations in American Literature, 1891-1955 (Durham, N.C., Duke U.P., 1957, p1. X, 100, \$2.00, paper covers). This is a most useful bibliography, listing pore than 2500 theses produced at about 100 universities in the U.S. and Europe. Titles have been arringed alphabetically by subject, first by individual authors, then by general topics. The writers of the theses are indexed seperately.

- Allan Houst on Macdonald, Richard Hovey: Man and Craftsman (Duke U.P., 1957, pp. xiii, $265,35.00)$; a critical biography of an American man of letters and bohemian of the 1890's, who like his contemporaries Frank Norris and Stephen Crane dited young -- in 1900, at the age of 35. His personality is nore interesting than $k_{1 i}$ work.

- Hans Galinsky, Amerikanisches und Britisches Englisch (Studien und Texte zur Englischen Fhilologie, Band 4; Max Hueber Verlag, Munich 13, 1957, pp. viii,96, DM. 7.90, paper covers). Two intelligent, competent and entertaining essays, of which the first is in German and the second in English, by an observer who visited Anerica in 1955. He considers the extent to which "American" and "English" have diverged, and gives examples of American English "as an index to Arerican culture" and as "a linguistic exchenge partner"(as revealed in recent 